\title{
ANALIZA ARHITECTURII DIN FAVELA ROCINHA UTILIZÂND BANDA DESENATĂ
}

asist. dr. arh. Gențiana Dumitrașcu

Universitatea de Arhitectură și Urbanism „Ion Mincu”, București

gentianacristinaiacob@yahoo.ro

\section{Rezumat}

Având ocazia să explorez arhitectura favelei Rocinha și în același timp să îmi dezvolt cercetarea prin realizarea unui nou experiment, care poate dovedi faptul că elementele caracteristice benzii desenate pot fi o manieră alternativă de a explora și analiza, de această dată, arhitectura unuia dintre cele mai haotice și controversate spații, alături de un alt coleg arhitect, am desfășurat un workshop de două săptămâni împreună cu elevii unei asociații din Rio de Janiero. Pentru a putea începe o analiză în care detaliem compoziția arhitecturală a uneia dintre cele mai mari favele din Rio de Janiero, acest oraș în oraș, trebuie să luăm în calcul toate straturile suprapuse de informație: violența zilnică, sărăcia, starea proastă în care se află sistemul educațional, probleme care țin de curățenie și sănătate, dar și spațiul colorat și vibrant al străzilor înguste care străbat această compoziție urbană fără nicio regulă aparentă. Din punctul nostru de vedere, pentru a putea începe o analiză onestă a acestui spațiu, trebuie să petreci timp trăind, discutând și lucrând alături de locuitorii favelei. Desenând și discutând despre arhitectura pe care o experimentează zi de zi, alături de elevii asociației Tio Lino, am avut șansa să investigăm spațiul construit, adăugând analizei informații noi culese cu fiecare interviu luat și fiecare experiență trăită alături de ei, în timp ce am detaliat alături de copii și ce înseamnă meseria de arhitect, cum putem desena ceea ce ne înconjoară, după ce am analizat cu atenție și cum putem ilustra soluțiile pe care le oferim problemelor identificate.

Cuvinte cheie: bandă desenată, favela Rocinha, secvență, narațiune, straturi 


\section{Introducere}

Un mod de exprimare bogat și variat, mediul grafic flexibil al benzii desenate, care combină în structura ei elementul narativ, spațiu și mișcare, a avut întotdeauna o strânsă legătură cu noțiunea de arhitectură, deținând un mare potențial pentru a construi povești puternice despre oameni, locuri și emoții. Finalizând teza de doctorat Comicopolis. Arta secvențială, un mod alternativ de a prezenta, discuta și proiecta arhitectura, care analiza prin studiu teoretic, interviuri și experimente, modalitatea în care elementele caracteristice benzii desenate pot îmbunătăți reprezentarea tradițională de arhitectură, felul în care investigăm arhitectura dar și cum o proiectăm, mi-am continuat cercetarea cu o serie de proiecte și experimente. Intrând în contact cu rezultatele workshop-ului pe care l-am desfășurat alături de colega arhitect, Brîndușa Tudor, în Namibia, în 2012, un angajat al unui ONG în favela Rocinha, mi-a propus să mă gândesc la un experiment similar, pe care aș putea să-I dezvolt alături de elevii cu care asociația lor lucra. După două săptămâni de desenat, intervievat și experimentat spațiul unuia dintre cele mai controversate compoziții urbane, am produs o bandă desenată colectivă, monocromă despre arhitectura favelei.

\section{Cuibul nostru în lume}

„Un muncitor fără unelte“, așa cum istoricul francez Jules Michelet o denumește, o pasăre își construiește cuibul folosindu-și doar corpul, pe care îl utilizează pentru a aduna materialele, pentru a le pregăti, pentru ca apoi să construiască întreaga structură. Forma interioară a cuibului este obținută de către pasăre prin împingerea permanentă a pieptului în construcția clădită. Silueta rezultată în urma acestui set de acțiuni urmărește perfect conturul corpului păsării. „Casa noastră reprezintă cuibul nostru în lume” (Robinson 2019, 12-13).

Arhitectura unei clădiri adună laolaltă viețile oamenilor care o întrebuințează, structurându-le și unindu-le existențele, creându-se, astfel, o puternică conexiune între spații și cei care le folosesc. Această relație este perfect subliniată de versul poetului francez, Noel Arnaud, „Eu sunt spațiul în care mă aflu" [ "Je suis l'espace ou je suis»]. Când un arhitect proiectează o casă începe, simultan, procesul prin care creează tiparul vieții celui care urmează să folosească spațiul. Momentul în care cel care utilizează spațiul începe să locuiască în clădirea propusă de arhitect, va aduce, la rândul său, modificări arhitecturii, adăugând un nou strat, odată cu fiecare schimbare apărută în viața, în familia sau în rutina sa. În final, după ce se face o analiză a tuturor straturilor suprapuse, spațiul rezultat va putea explica felul în care cel care l-a ocupat a trăit. Winston Churchill afirma, de altfel, în 1943, în timp ce discuta despre reconstrucția Casei Comunelor, că „noi modelăm clădirile, pentru ca apoi, ele ne modelează pe noi”.

În Poetica spațiului, Gaston Bachlard consideră casa „prima lume a ființei umane”, „trup și suflet”, adăpostul care ne protejează de „furtunile cerului și furtunile vieții”, iar toate casele în care am locuit în trecutul nostru, vin, odată cu noi, să se adăpostească în noul spațiu pe care îl locuim (Bachelard 2003, 37). Căci, atunci când vom derula amintirile casei, al primului univers al nostru, vom fi rareori istorici onești. Vom atașa de ele valori ideale, lăsând „trecutul să vină prin vis să viețuiască în casa nouă".

\section{Favela a luat naștere}

În articolul său, în editorialul The Guardian, despre nașterea și căderea în ruină a primei favele din Rio, Morro da Providencia, jurnalistul Bruce Douglas, afirmă că favela, exercită o fascinație 
duală. Acest tărâm al libertății înșelătoare, care poate să fie considerat un oraș în interiorul altui oraș, oscilează mereu între seducția pe care cultura populară o atribuie acestui spațiu și realitatea în care este sursa principală a violenței, sărăciei și bolilor. Cum spune personajul principal, Ozgur, din romanul Orașul în mantie purpurie al lui Asli Erdogan, tânăra scriitoare de origine turcă, care petrece trei ani zbuciumați în faimosul oraș brazilian, Rio este, până la urmă, orașul în care „ordinea și haosul sunt legate în mod intim” (Erdogan 2019, 140). Scriitoarea alege să petreacă trei ani, plini de nenumărate încercări, în faimosul oraș brazilian, pe care îl definește ca fiind "o frumusețe înșelătoare care aprecia extremele, contradicția și lipsa măsurii" (Erdogan 2019, 67).

Lupta celor doi tineri bărbați din Paris încercând să deschidă un cabaret în favela Providencia, atât pentru turiști, cât și pentru locuitorii orașului în căutare de senzații noi, ilustrată în filmul Favela dos Meus, Amores (Favela iubirilor mele), din anul 1935, în regia lui Humberto Mauro, a fost unul dintre primele filme care și-a concentrat acțiunea asupra vieții din favelă, a locuitorilor săi, dar și asupra muzicii braziliene. Deși filmul a fost pierdut în anii 1970 și alte copii nu au fost găsite, moștenirea acestuia a devenit din ce în ce mai puternică de-a lungul anilor, datorită regizorilor, precum Alex Viany, care l-au numit „primul film brazilian care a exploatat cu adevărat unul din cele mai tragice, exuberante și muzicale spații ale orașului Rio: favela." în timp ce personajele principale erau interpretate de actori profesioniști, regizorul a ales să includă printre actorii care făceau figurație atât dansatorii școlii de samba din Providencia, cât și locuitori din această zona a orașului brazilian, aducând peliculei odată cu această intervenție, caracteristici ale filmului documentar, reușind să nu „denatureze caracterul favelei", după cum afirma, mai târziu, scriitorul Jorge Amado. Mauro a controlat perfect compoziția filmului, încorporând în povestea dramatică, scene comice și momente emoționante, expunându-și intențiile artistice cu declarația „am luat pur și simplu viața din favelă, așa cum era ea și am documentat-o" (Dennison, Shaw 2004, 49).

Providencia, prima favelă braziliană, a fost construită în 1897, de soldați care au ajuns în Rio ca să își primească plata din partea guvernului, pentru reușita armatei de a înăbușit răscoala țăranilor, în Nord - Estul Braziliei, în timpul războiului din Canudos, din Bahia. Neprimindu-și banii, au ales să nu mai plece și să se stabilească majoritatea, în Rio, în adăposturi improvizate. Considerați în anii 1920 de locuitorii orașului Rio ca sursa principală a criminalității, iar de guvern ca un obstacol în calea dezvoltării urbane, numărul locuitorilor din favele a crescut în anii 1940, când criza locuințelor a atins cote îngrijorătoare, forțând populația urbană săracă, atrasă în marele oraș de industrializarea propusă de președintele Getulio Dornelles Vargas, să ridice sute de ghetouri, în suburbiile orașului. Însă, favelele moderne au apărut în anii 1970, ca o consecință directă a exodului populației braziliene, când locuitorii din zonele rurale au migrat spre orașe, în căutarea unei vieți mai bune. Odată ajunși în Rio, emigranții cu venituri mici s-au confruntat cu prețurile mari ale pământului și locuințelor, neavând nici o altă opțiune decât să își construiască adăposturi ilegale. Datorită lipsei de sprijin din partea guvernului și a unui program prin care ar fi trebuit să crească numărul locuințelor, numărul acestor așezări improvizate a continuat să crească. În Rio de Janiero, între anii 1950 și 1980 numărul rezidenților favelor a crescut de la 170.00 la 600.000 și, la începutul secolului XXI, estimările arătau că numărul favelor s-a ridicat la 1.000. Creșterea substanțială a atras, în cele din urmă, atenția guvernului brazilian care a decis, în anii 1960, să încerce să eradice aceste așezări controversate, printr-un program de relocare a locuitorilor acestora în ansambluri rezidențiale, precum Cidade de Deus, comunitate făcută cunoscută publicului larg, datorită filmului ce poartă același nume, din anul 2002. Această acțiune a fost, în cele din urmă declarată un eșec, 
deoarece, datorită unei planificări defectuoase și a resurselor financiare limitate acordate proiectului, noul ansamblu rezidențial s-a transformat, la rândul său, într-o nouă favelă. În anul 1991, un studiu condus de Instituto de Planejamento in Rio de Janiero (IPLAN-Rio), susținea că în oraș există un număr total de 661 de favele, care adună 962.793 locuitori, în 239.678 de barăci (Pino 1997, 111). Statisticile realizate și făcute publice de Institutul Brazilian de Geografie și Statistică, în Decembrie 2011, au prezentat că, în anul 2010, 6 procente din populația Brazilia locuia în favele (IBGE, Census, 2010).

Favelele din Rio oferă ocazia perfectă pentru a investiga cum este reprezentată în Brazilia inegalitatea socială. Condițiile inadecvate de trai și sprijinul guvernamental slab au lăsat aceste așezări expuse producției și traficului de droguri, devenind astfel, în anii 1980, puncte de interes ale Americii Latine, predominate de violențele găștilor, de traficul de arme și de droguri. Violențele au continuat să crească, iar favele, prin care treceau anual milioane de dolari, au devenit conduse ilegal de traficanții de droguri și arme. În anul 2008, guvernul brazilian a decis să intervină, amplasând în ghetourile cu o rata crescută a criminalității grupuri de polițiști care, după o serie de ciocniri violente cu membrii găștilor, au reușit să obțină, în unele cazuri, condiții mai sigure de trai pentru rezidenții acestor comunități.

Favelele sunt considerate un punct slab în infrastructura orașului, o greșeală de care urbaniștii și arhitecții brazilieni încearcă să se delimiteze, propunând mutări forțate în ansambluri noi construite, sau construind telecabine deasupra acestor comunități, încurajând un ciudat turism intruziv. Sau își doresc să devină spații invizibile. Însă locuitorii acestor comunități lucrează la o reprezentare corectă și onestă a felului în care le este prezentată viața și mai ales insistă asupra necesității de a avea condiții de trai decente, dar și ilustrează felul în care această tipologie urbană s-a dezvoltat, de-a lungul decadelor, independentă de propunerile urbanistice existente, prin organizații precum Favelas in Mare sau Raize em Movimento do Complexo do Almao. (Palmer, Nitsch 2014, 9).

\section{Tio Lino din favela Rocinha}

Rocinha, situată în Rio de Janiero, este cea mai mare favelă din Brazilia. Construită pe un deal abrupt, înconjurată de vegetație bogată, această favelă adăpostea între 150.000 și 300.00 de locuitori în anii 2000, pentru ca în anul 2017, publicația englezească The Economist să raporteze că Rocinha avea o populație de 100.000 de locuitori, pe o suprafață de 250 de acri $\left(1 \mathrm{~km}^{2}\right)$. Fiind considerată o mahala urbanizată, cu un număr considerabil de clădiri construite din cărămidă sau beton, cu instalații sanitare rudimentare, deservită de un sistem de canalizare și având electricitate, Rocinha are, în comparație cu alte ghetouri, o infrastructură mai puternică, dar și un număr neașteptat de mare servicii locale (magazine de haine, magazine alimentare, cofetării, patiserii, sucursale de bănci, farmacii și chiar cabinete de chirurgie plastică).

Frustrați de starea îngrijorătoare în care se află învățământul în aceste comunități, organizațiile non-guvernamentale din favele încearcă să lucreze cu numărul mare de elevi care nu au acumulat încă, în școli, noțiunile de bază (scris, citit, aritmetică), creând soluții pentru a rezolva problemele continue din acest sector, precum și lipsurile care apar ca o consecința a numărului insuficient de școli, a calității scăzute a profesorilor, a violenței și criminalității prezente din aceste zone. Deși rezultatele au început deja să apară, iar numărul elevilor prezenți în sălile de curs a început să crească în ultimii ani, în parte datorită comunităților care au început să se implice direct în acest proces, există, în continuare, un număr ridicat de analfabeți funcționali 
care promovează cursurile școlilor braziliene (The Brazilian Report 2017). În ciuda progresului general, ca efect al creșterii numărului elevilor înregistrați în școlile braziliene, care au acum acces la educație și o creștere semnificantă a numărului celor care frecventează cursurile instituțiilor educaționale, într-un interval de cincisprezece ani, conform raportului OECD din anul 2010, există un procent mare de analfabetism în rândul elevilor, care încă au probleme atunci când trebuie să rezolve exerciții de bază, să citească sau să scrie. Una dintre organizațiile non-guvernamentale din favela Rocinha este Tio Lino (Unchiul Tio), care a fost creată de un locatar al favelei, în 2002, care și-a dorit să creeze un spațiu sigur pentru locuitorii acestei comunități care decideau să își schimbe modul de abordare a traiului zilnic. Acesta încuraja brazilienii din Rocinha să își lase armele, care erau considerate de populația din ghetouri, singura modalitate de a comunica, pentru ca apoi să le poată preda, în siguranță, polițiștilor. Toți cei care frecventează asociația sunt implicați în proiecte culturale, artistice, sunt învățați să scrie, să citească, sau au, pur și simplu, un loc sigur în care puteau să se întâlnească cu voluntari dornici să-i ajute. Proiectul bază, la care se lucrează de mai bine de două decenii, se numește „Rocinha Waldorf Art Project - Trade your weapon for a brush”, care încearcă să adune toate creațiile artistice realizate de locuitorii din Rocinha, în încercarea de a provoca populația braziliană să vadă rezidenții acestei comunități și altfel decât indivizi violenți, periculoși și lipsiți de o educație școlară de bază. În urma decesului lui Lino, survenit acum doi ani, fiica sa, Iris, sponsorizată de doi tineri voluntari din Anglia, continuă viziunea tatălui său, sub numele ACE (Accelerating Community Empowerment).

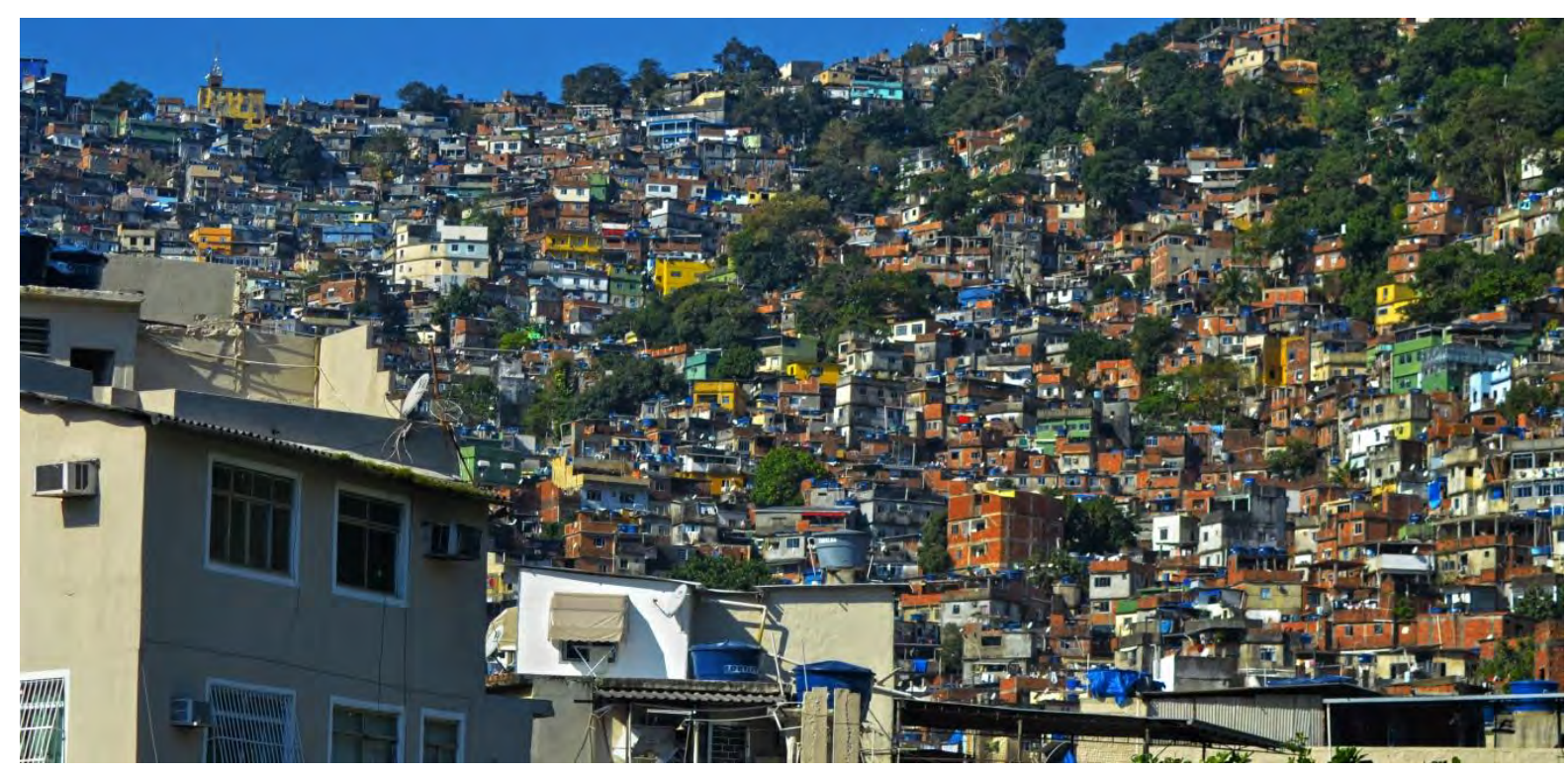

Fig. 1. Rocinha favela.

Sursa: Imagine de Gențiana Dumitrașcu

\section{Obiective}

Obiectivul nostru a fost să realizăm un altfel de analiză arhitecturală, o posibilă primă etapă a unui studiu mai cuprinzător, folosind elementele definitorii benzii desenate, în timp ce am experimentat, zi de zi, starturile suprapuse de arhitectură din favela Rocinha și am creat legături cu locuitorii acestei comunități. Am considerat un exercițiu valoros analizarea arhitecturii acestei favele, interviurile desfășurate cu locatarii și dezvoltarea unei benzi 
desenate, alături de elevii care lucrează cu asociația Tio Lino, detaliind cum este să trăiești înconjurat de arhitectura haotică din Rocinha. Bineînțeles am apreciat ocazia pe care am avuto de a experimenta ceea ce înseamnă să fii zilnic în favelă, în condiții de siguranță.

\section{Materiale și metode}

Utilizând elementele caracteristice ale benzii desenate, acest mediu hibrid de reprezentare, care combină în structura lui narațiunea, spațiul și mișcarea, alături de un alt coleg arhitect, Andrei Dumitrașcu, am condus un workshop de 2 săptămâni, cu o parte din copiii care participau la cursurile asociației Tio Lino. Banda desenată, un produs colectiv, rezultatul conversațiilor pe care le-am avut cu cei 9 elevi, a fost încercarea acestora de a înfățișa punctul lor de vedere, atunci când au detaliat ce înseamnă să locuiești în această comunitate. Am discutat, am dezbătut și am desenat alături de ei, felul în care ei percep favela, cum arăta drumul de acasă la școală, sau cum este cel de acasă la asociație, dar și care este locul lor preferat în favelă. I-am îndemnat să identifice o serie de nereguli pe care le observă în Rocinha și i-am încurajat să încerce să găsească soluții.

De asemenea, am dorit să documentăm cât mai multă informație, în vizite noastre zilnice în favelă, așa că, am decis să desfășurăm o serie de interviuri cu rezidenții acestei comunități. Aceste discuții au avut la bază un scurt chestionar, pregătit înainte de a pleca în Brazilia, dar care a fost adaptat pentru fiecare interlocutor și situație. Chestionarul era format din 5 întrebări: De cât timp locuiți în favelă? Sunteți proprietarul locuinței dumneavoastră? Puteți identifica cea mai presantă problemă cu care rezidenții Rocinhei se confruntă zilnic? Puteți numi 3 lucruri pe care le agreați atunci când vine vorba de a trăi în favelă? Care este cea mai importantă informație pe care locuitorii din Rio, politicienii și străinii ar trebui să o știe despre favela Rocinha?

\section{Fragmente de jurnal: incursiune în favelă}

Imaginea Rocinhei este copleșitoare. Cred că ochiului antrenat, în mare parte, cu peisajele urbane specifice Sud - Estului Europei, îi este greu să înregistreze, în câteva clipe, cantitatea mare de informație de culori, forme și texturi, pe care o oferea cea mai mare favelă din Rio, de fiecare dată când ieșeam din subteran, din stația de metrou pentru a ne începe drumul către Tio Lino.

Ca să ajungi la asociație, drum pe care l-am parcurs în primele două zile însoțiți, apoi singuri, trebuia să te strecori, în șir indian, prin aleile înguste ale unei piețe improvizate, pentru a reuși, mai întâi, să ajungi la una dintre intrările recomandate în favelă. De cele mai multe ori, făceam acest lucru, fără să scoatem prea multe cuvinte, încercând să exersăm câteva din sfaturile primite, pentru a fi în siguranță. Piața acoperită și aglomerată era alcătuită dintr-o înșiruire de tarabe multicolore, pe care erau îngrămădite, fără o ordine anume, copleșitor de multe produse vestimentare, imitații de tot felul, bijuterii din tinichea, jucării, umbrele, ceasuri etc. Printre tarabe, puteai identifica câte o mică cofetărie sau patiserie, care nu ducea, indiferent oră, lipsă de clienți. Apoi, după ce ieșeai, din nou, în soarele surprinzător de puternic pentru un final de iarnă, început de primăvară, la prima intersecție, relativ generoasă, în termenii infrastructurii Rocinhei, trebuia să te aventurezi pe aleile înguste, delimitate de magazine improvizate la parter, să ocolești copii care alergau bucuroși în toate direcțiile, adulți care ori stăteau de pază, măsurându-te din cap până în picioare și clasându-te, cu ușurință, în categoria din care făceai parte (localnic, vizitator ocazional, voluntar, polițist, traficant), ori erau 
preocupați să își rezolve disputele lor, sau se bucurau de o după-masă însorită, unduindu-se pe ritmurile care se auzeau din aparatele radio, de mici dimensiuni, așezate direct pe trotuar. Am fost avertizați, din timp, că în favelă am putea fi opriți doar de reprezentații celor mai importante două categorii: traficanții de droguri sau polițiști. Exista, însă, o mică posibilitate, să se întâmple acest lucru, căci membrii celor două tabere, aveau o vastă experiență în a analiza trecătorii și își puteau da seama, cu rapiditate că, deși încercam să ne pierdem printre cei 150.000 de locuitori, eram, cu siguranță, străini, cel mai probabil, voluntari. Deși favelele sunt considerate cele mai periculoase locuri din Brazilia, ne-am simțit, pe parcursul săptămânilor petrecute în Rocinha, mult mai în siguranță aventurându-ne pe aleile înguste, decât în afara ei. Pe străzile din Rio trebuia să fii atent la orice mișcare pe care o făceai, trebuia să te ferești de oamenii străzii, nu tocmai pașnici, care se află în număr foarte mare, în orice zonă a orașului, să încerci să identifici posibilii hoți de buzunare, de orice vârstă, care puteau deveni, foarte frecvent, violenți. Dar, în Rocinha trebuia doar să ne ferim din calea unei eventuale dispute dintre traficanții de droguri și polițiștii care făceau raiduri dese în favelă, pentru a nu deveni, astfel, simple victime colaterale. Altfel, pentru cele două tabere principale din această comunitate, aflate în conflict permanent, nu prezentam prea mult interes.

Pe străzile principale, care urcă și coboară dealurile pe care este ridicată favela, circulă neîncetat autobuze, microbuze și moto-taxi-uri, principalul mijloc de transport din Rocinha, pe cât de ieftin, pe atât de palpitant, datorită mișcărilor iscusite, pe care șoferii le fac la milimetru. De-a lungul acestor artere se ridică clădirile cele mai înalte, în unele cazuri, de șase, șapte etaje, cu magazine așezate la parterul placat cu piatră, sau faianță la exterior, vopsite în culori puternice. În cazul clădirilor de locuințe, rezidenții aleg de cele mai multe ori să lase cărămida expusă, nefolosind niciun alt finisaj, iar acoperișul este (la fel ca și în cazul sediului asociației Tio Lino) din tablă, decorat cu antene și rezervoare albastre de apă. Majoritate ferestrelor, în special a celor de la parter, a celor de la etajele inferioare dar și intrările sunt protejate de gratii, lucru întâlnit de altfel la majoritatea imobilelor din Rio, indiferent de zona în care se aflau. Interioarelor locuințelor li se acordă, în schimb, multă atenție, fiind vopsite în culori vii, finisate cu faianță și gresie, iar fiecare încăpere este acompaniată de câte un ventilator.

\section{Rezultatele workshop-ului de bandă desenată}

Din discuțiile și planșele realizate am concluzionat că aleargă cu bucurie, pe străzile înguste ale favelei, că se simt copleșiți, nu numai atunci când trebui să le deseneze, de numărul mare de clădiri care îi înconjoară, dar adoră culorile vii în care aceste sunt vopsite și sunt încurcați de numărul mare de cabluri, prezente la fiecare colț, folosite de locuitori pentru a fura electricitate. Deși au vârste fragede, observă cu ușurință și sunt afectați de o mare parte din problemele cu care se înfruntă Rocinha: lipsa siguranței, numărul ridicat al mamelor adolescente (una dintre eleve, atunci când a fost îndemnată să ilustreze ceea ce consideră ea că este o problemă pe care o vede în favelă, a prezentat tragedia unei verișoare care a rămas însărcinată, și care plângând povestea familiei că nu va avea cu ce să își hrănească sau îmbrace noul născut), lipsa mâncării, mai ales când provin din familii numeroase, dar și condițiile precare sanitare, prezente în cea mai mare parte a Rocinhei. După ce au identificat problemele, elevii au oferit mici soluții pentru problemele pe care le-au observat, în marea lor majoritate, definite de inocența, încă nealterată, specifică vârstei. Cele mai originale soluții, dar și ilustrații au fost oferite de Maycon, un elev sclipitor de 11 ani, provenit dintr-o familie cu alți șapte frați, care, însă întâmpina probleme atunci când trebuia să insereze texte în desenele lui, sau să ne citească ceea ce cu dificultate scrisese. 


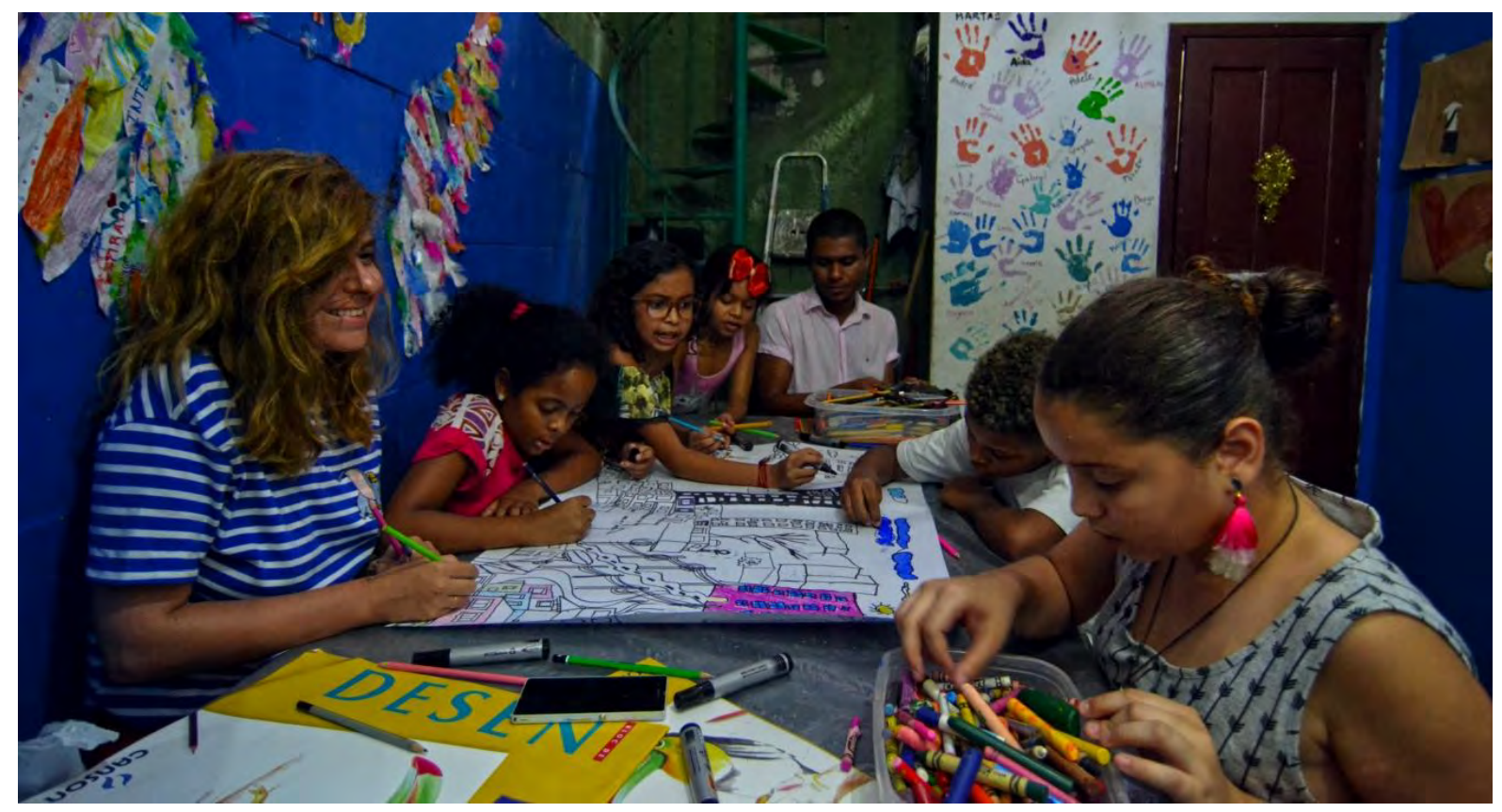

Fig. 2. Elevii asociației Tio Lino. Sursa: Fotografie de Andrei Dumitrașcu

Foarte dificil a fost, din primul moment, să-i determinăm pe elevii care participau la experiment să rămână concentrați mai mult timp asupra unui cadru al compoziției și să reușim să-i angajăm într-o discuție detaliată despre ce își doresc să deseneze. S-a întâmplat, în cazul a trei fetițe cu vârste cuprinse între 8 ani și 10 ani să își dorească să termine foarte repede ceea ce aveau de desenat într-o ședință, atunci când au realizat, că poate nu este cel mai ușor exercițiu pe care I-au desfășurat, până atunci. Într-o discuție ulterioară despre cum evoluează ședințele noastre de lucru, cu unul din voluntarii care petrecuse 2 ani lucrând în asociație, aceasta mi-a împărtășit din experiența ei, spunându-mi că, rareori, la școală, sunt încurajați să își păstreze concentrarea pentru o perioadă mai lungă de timp, iar o perseverență moderată este o excepție care se regăsește mai degrabă, în cazul puținilor elevi, ai căror părinți sunt foarte implicați în educația lor, nu în cazul majorității.

Pentru că, din păcate, timpul petrecut cu ei, era limitat și nu am fi avut posibilitatea să explorăm mai multe tehnici de reprezentare, le-am propus elevilor să abordăm acest exercițiu doar în tonuri alb-negru, de aceasta dată, iar la finalul ședințelor, să alcătuim o planșă mare, colectivă, în creioane colorate, înfățișând percepția noastră asupra favelei. Disputele cele mai intense au intervenit între ei, atunci când, am început să limităm accesul la guma de șters. Ne doream să le explicam că este foarte important să încercăm să gândim în detaliu ceea ce vrem să desenăm înainte să trasăm o linie, să depunem un mic efort pentru a ne aduna gândurile, să le ordonăm, apoi să le ilustrăm, dar și că nimic din ceea ce desenează ei noi nu vom considera a fi o greșeală, ci doar o etapă a procesului, pe care o putem modifica, adapta, odată apărută pe planșa lor. Am avut, la acest capitol, mici victorii, de-a lungul zilelor care au urmat, însă, atunci când discuțiile deveneau prea încinse, căci o linie aparent greșită, poate de multe ori să umezească ochii unui copil de 7 ani, făceam o mică concesie și îi rugam să mă lase pe mine să-i ajut să înlăture, sau să adaptez, ceea ce ei considerau, greșeli catastrofice pe planșa lor. Lipsa exercițiului de a depune un efort constant și-a spus cuvântul la acest capitol. 

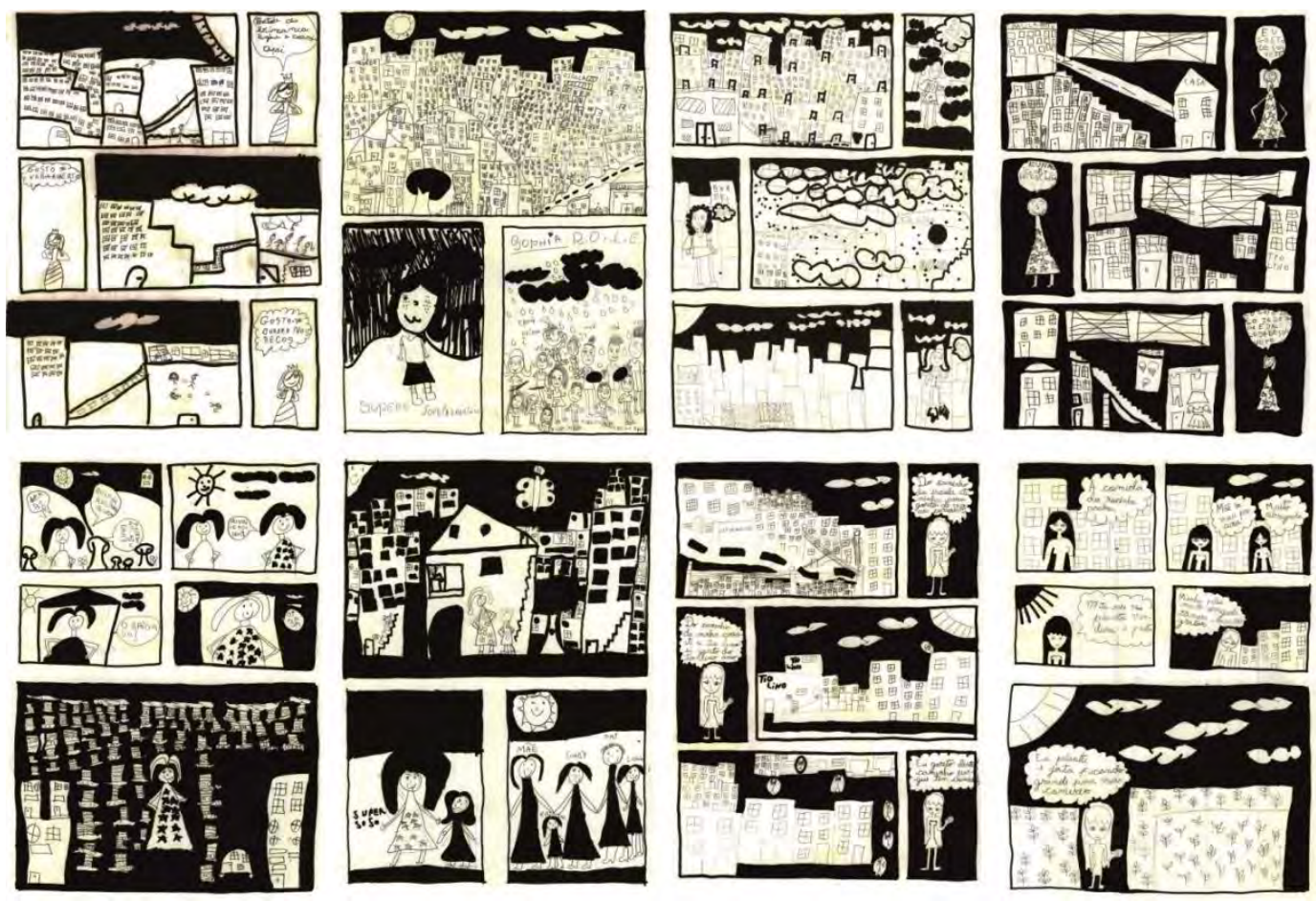

Fig. 3. Fragmente din banda desenată realizată de elevii asociației Tio Lino.

Deși erau limpede conștienți de aglomerația de informație din favelă, am reușit să-i convingem treptat, să mai adauge, rând pe rând, ca rezultat al conversațiilor și încurajărilor noastre, câte un strat de clădiri, de ferestre (și să-i convingem să părăsească forma dreptunghiulara în cazul lor), cabluri, antene parabolice, rezervoare de apă, câini, pisici, moto-taxi-uri etc.

Purtând conversații cu locuitorii favelei am aflat că: nu există nici un fel de reglementare urbanistică; respectul reciproc între vecini este decisiv atunci când se aduce în discuție o nouă adiție a unei clădiri; sfatul unui arhitect sau a unui inginer este folosit numai pentru clădiri mai mari de trei etaje, iar pentru restul imobilelor sunt folosiți un grup mic de muncitori, sau membri ai familiei, care se ocupă atât de proiectul construcției, cât și de realizarea ei; poți să vinzi suprafața acoperișului casei în care locuiești, unui alt proprietar, pentru ca acesta să o construiască pe a lui deasupra locuinței tale (asta în cazul în care alt un membru al familiei tale nu își dorește să se stabilească în acel spațiu); locatarii nu plătesc pentru electricitate, apă sau internet (toate aceste fiind furate) și deși rezidenții comunității încă se luptă cu boli care apar ca o consecință a lipsei condițiilor sanitare adecvate (gunoiul este rar colectat la timp, iar sistemul de canalizare are multe nereguli), guvernul Brazilian face mai multe investiții în Rocinha. Nu toate investițiile sunt, însă, apreciate de brazilienii din această comunitate. Una dintre cele mai disputate este podul construit de arhitectul Oscar Niemeyer, care a costat aproximativ nouă milioane de dolari, care leagă favela de restul orașului Rio. Locuitorii comunității se simt mândri atunci când privesc lucrarea recunoscutului arhitect brazilian, dar, în același timp, cred că, suma generoasă de bani folosită pentru proiectarea și realizarea acestuia, putea fi folosită pentru a rezolva multe alte probleme urgente cu care se înfruntă zilnic ghetoul. 
Cea mai mare parte a rezidenților își doresc ca să devină proprietari ai terenurilor pe care și-au construit imobilele, iar programele de relocare, oferite de guvernul brazilian să fie evitate, iar în locul acestora, comunitățile lor să beneficieze de investiții care ar sprijini: un sistem de canalizare adecvat, lărgirea arterelor și colectarea gunoiului.

Adams, în vârstă de 28 ani, care lucrează în Rocinha, la organizația non-guvernamentală Tio Lino și trăiește în Santa Marta și cu care am petrecut o mare parte din timpul nostru, el fiind ghidul nostru în favelă, ne-a prezentat în detaliu cum trebuie să ne comportăm, pe unde și când trebuie să mergem ca să fim în siguranță, dar și ce să le răspundem traficanților de droguri și polițiștilor când ne vor întreba ce căutăm în acea parte a orașului, ne-a povestit, în detaliu, ce impedimente întâmpină cei care locuiesc în favelă, dar, aleg să lucreze în afara ei. Bineînțeles, trebuie să fii în alertă permanentă pentru a nu deveni victimă colaterală în ciocnirile dintre polițiști și reprezentanții cartelurilor de droguri. Rezidenții au grupuri speciale on line în care se anunță reciproc dacă se desfășoară un schimb de focuri, pentru a evita intrarea sau ieșirea din favelă în acel moment și a rămâne la adăpost. După cum se întâmplă frecvent, în cazul mai multor locuitori ai acestei comunități, a pierdut două slujbe pentru că, în încercarea de a evita ciocnirile violente repetate dintre cele două tabere, ajungea cu întârziere la locul de muncă, sau era obligat, fără posibilitatea de a da un preaviz, să lipsească o zi întreagă.

\section{Impactul emoțional al favelei}

Istoricii Alba Zaluar și Marcos Alvito au publicat o scrisoare găsită în arhivele naționale, scrisă pe data de 4 Noiembrie 1900, în cartea Un Seculo de Favela, publicată în anul 1998. Doar la trei ani după ce favela Morro da Providencia a luat naștere, aceasta începuse deja să aibă o reputație nefavorabilă, conform plângerilor unui ofițer, care încerca să descrie dificultățile întâmpinate în încercarea de a combate criminalitatea din această mahala:

A îți face treaba de polițist în această zonă, plină de dezertori, hoți și escroci este imposibil. Nu există străzi, casele sunt făcute din lemn și acoperite cu zinc și nu există nici măcar un felinar cu gaz pe tot dealul. (Douglas 2016)

Problemele care apar în timpul combaterii criminalității din aceste zone și implicațiile complexe ale conflictului dintre traficanții de droguri și reprezentanții guvernului brazilian influențează și astăzi natura și calitatea vieții civice în favele. Cartelurile sunt bine consolidate iar relația tumultuoasă pe care o au cu statul domină viața socială în ghetouri.

În săptămânile petrecute în Rocinha, am fost, de asemenea, spectatorii unui moment dificil, când în timpul unui raid al poliției un număr de suspecți au fost arestați. Totul s-a întâmplat când, într-o după-masă, ne pregăteam să intrăm în favelă, pentru a începe o ședință de lucru cu elevii de la Tio Lino. Pe drumul către asociație, am întâlnit numeroși civili tineri, înarmați, pregătiți de un nou conflict cu poliția braziliană, iar când am ajuns în curtea ONG-ului, a început schimbul de focuri. Primul meu gând, nefiind o persoană obișnuită cu acest zgomot, a fost că ceea ce se aude sunt focuri de artificii. Bineînțeles, nu erau. Din fericire, nimeni nu a fost rănit în urma conflictului. Nimic din cele petrecute nu a avut asupra mea un impact mai mare precum reacția copiilor. I-am întrebat, în portugheza braziliană șubredă pe care mă chinuisem să o învăț înainte de acest drum și pe care mă încăpățânasem să o exersez pe tot parcursul zilelor petrecute în Rio, dacă le este frică. Mi-au zâmbit simplu și mi-au răspuns că nu, „ne-am obișnuit deja, doar că nu o să ne întoarcem singuri acasă, o să ne așteptăm mamele să vină să 
ne ia. " Aceea era casa lor, plină de neajunsuri, periculoasă și foarte des, pur și simplu haotică, însă plină de energie și culoare, iar ei se adaptaseră la tot ceea ce însemnă, în acest moment, favela Rocinha.

\section{În loc de concluzie}

Oricât te-ai pregăti teoretic, pentru experiența de a lucra în favela Rocinha, dacă nu explorezi, în detaliu, particularitățile spațiului acestui oraș în oraș, nu poți conduce o analiză onestă și coerentă. Cât timp studiezi această comunitate este necesar să iei în calcul toate suprapunerile complexe de straturi care au condus la condițiile de trai prezente. Desenând și discutând arhitectura favelei, alături de elevii care frecventau asociația Tio Lino, am avut oportunitatea să discutăm despre o mare parte din problemele locuitorii favelei. Efortul depus de noi de a termina proiectul în condiții departe de a fi perfecte, a câștigat încrederea unor rezidenți în vârstă, care, astfel, au fost de acord să discute cu noi, îmbogățindu-ne cercetarea. Acest experiment poate să fie un punct de plecare pentru o colaborare pe termen lung, în care, după finalizarea studiului nostru, putem propune mici intervenții pentru a îmbunătăți o parte din condițiile de trai din favela Rocinha.

\section{Referințe}

Ahrens, J. (2010) and Meteling A. Comics and the City. Urban Space in Print, Picture and Sequence. New York: Continuum.

Bachelard, G. (2003). Poetica spaţiului. (I. Bădescu, Trans.). Piteşti: Paralela 45.

Dennison S, Shaw L. (2004). Popular cinema in Brazil. Manchester: Manchester University Press.

Douglas, B. (2016): The story of cities \#15: the rise and ruin of Rio de Janeiro's first favela. The Guardian, on-line article.

Eisner, W. (2008) Graphic storytelling and visual narrative: principles and practices from the legendary cartoonist. New York: W.W. Norton \& Company Inc.

Erdogan, A. (2019). The city in crimson cloak (Kirmizi Pelerinli Kent). București: Polirom.

Pino, J.C. (1997). Sources on the history of favelas in Rio de Janeiro. In Latin American Research Review (Vol. 32, no. 3). (pp. 111-122). The Latin American Studies Association. Jstor Academic Database

Robinson, S. (2019). A-ți face cuibul: Trup, Casă, Minte (Nesting: Body, Dwelling, Mind). (Stanislav C. , Trans.). București: Arhitext.

The Brazilian Report (2017). Brazil's failed educational system creates illiterate students. The Brazilian Report on-line article 


\title{
INVESTIGATING THE ARCHITECTURE OF ROCINHA FAVELA USING ARCHITECTURAL COMIC STRIPS
}

assist. PhD Gențiana Dumitrașcu

Affiliation: University of Architecture and Urbanism „Ion Mincu”, Bucharest, RO

gentianacristinaiacob@yahoo.ro

\begin{abstract}
Having the chance to explore the architecture of the Rocinha favela and in the same time, to further my research with a new experiment, that can prove that the characteristics of the comic strip structure can be an alternative manner to explore and discuss, this time, the architecture of one of the most chaotic and controversial spaces, another fellow architect and I, developed a two week experiment with the students of a local NGO, in Rio de Janiero. In order to be able to start an analysis in which we can explore the architectural composition of one the largest favela in Rio de Janiero, this city in a city, we must take into account all the overlapping layers: the everyday violence, the poverty, the poor state of the education system, the health issues, but also the vibrant and colourful environment of the narrow streets that go through this urban composition, without any regulations. In our opinion, in order to start an honest exploration, you must spend time, living, talking and working with the residents, gaining their trust, day by day. Drawing and discussing about the architecture they experience every day, with the students of Tio Lino NGO, we had the chance to investigate the built space, adding more information with each interview we conducted and every experience we had working alongside them, while, also, talking with them about what it means to be an architect, how we can draw our surroundings, after carefully examining it and how we can illustrate the solutions we can provide to the problems we observe.
\end{abstract}

Keywords: comic strip, Rocinha favela, sequence, narration, layers 


\section{Introduction}

A rich and varied manner of expression, the flexible graphic medium of comic strips, which combines in their structure, the narrative element, space and movement, has always had a strong connection with the notion of architecture, having a big potential for constructing powerful stories about people, places and emotions. Having completed the doctoral thesis, Comicopolis. Sequential art, an alternative manner of presenting, discussing and designing architecture, which analyzed through theoretical study, interviews and experiments, the way the characteristic elements of comics can improve the traditional architectural representation, the way we investigate architecture and the also design process, I further continued my research with a series of experiments and projects. Coming across the results of a workshop I developed, alongside another fellow architect, Brîndușa Tudor, in Namibia, in 2012, an employee of the NGO in Rocinha proposed me to think of a similar experiment to conduct with some of the students enrolled in their association. After two weeks of working, interviewing and experiencing the space of one of the most controversial urban compositions, we produced a monochrome collective architectural comic strip.

\section{Nesting}

"A worker without tools", as the French historian, Jules Michelet calls it, a bird builds its nest following only its instinct, using the body to collect and prepare the necessary materials and, after that, composes the entire structure. The interior shape of the nest is a result of the permanent action of the bird pushing its chest into the built structure. The form resulted after this set of actions follows perfectly the shape of the bird's body. "Our home is our nest in the world" (Robinson 2019, 12-13).

The architecture of a building brings together the lives of its inhabitants, structuring and uniting their existences, thus creating a strong connection between space and those who occupy it. This relationship is perfectly underlined by the French poet, Noel Arnaud's verse: "I am the space, where I am" ["Je suis l'espace ou je suis"]. When an architect designs a house, he also starts the process of creating the pattern of the life of those who will occupy the space. The moment the dweller starts living in the building designed by the architect, he also starts modifying the initial architecture, adding a new layer with every change made to his life, family or routine. In the end, after analysing all the overlapped layers of information, we can explain how the occupant lived in that space. While discussing, in 1943, the reconstruction of the House of Commons, Winston Churchill also states that "We shape our buildings; thereafter they shape us".

In The Poetics of Space, Gaston Bachlard considers the house "the first world of the human being", "body and soul", the shelter that protects us from "the storms of heaven and the storms of life" and all the houses in which we have lived in our past come together with us, in the new space that we start to inhabit (Bachelard 2003, 37). Because, when we will go through the memories that we made in the previous house, our first Universe, we will rarely be honest historians. We will attach ideal values to them, letting "the past to come, like in a dream, to live, amongst us, in the new house."

\section{The birth of the favela}

In his article, in The Guardian, about the birth and ruin of the first Rio slum, Morro da Providencia, journalist Bruce Douglas affirms that the favela exerts a dual fascination. This 
realm of deceitful freedom, which can be considered a city within another city, always oscillates between the seduction that popular culture assigns to this space and the reality in which it is the main source of violence, poverty and disease. As the main character, Ozgur, says, in Asli Erdogan's novel, The city in the crimson cloak, Rio is after all, the city where "order and chaos are intimately linked" (Erdogan 2019, 140). The young Turkish writer spends three challenging years in the famous Brazilian city, being defined by "a deceptive beauty that appreciates extremes, contradiction and lack of measure" (Erdogan 2019, 67).

The struggle of the two young men from Paris to open a cabaret in the Providencia favela, for both tourists and city dwellers looking for new sensations, illustrated in the film Favela dos Meus Amores (The Favela of My Loves), from 1935, directed by Humbet Mauro, was one of the first movies that focused on the life of the favela, its inhabitants and, also, the Brazilian music. Although the movie was lost in the 1970s and no other copies were found, its legacy grew stronger over the years, thanks to directors like Alex Viany, who called it "the first Brazilian film that really exploited one of the most tragic, exuberant and musical spaces of Rio: the favela." While the main characters were played by professional actors, the director chose to include among the actors who performed, both dancers from the samba school in Providencia and residents of this area of the Brazilian city, offering the picture, with this intervention, characteristics of the documentary film, managing not to "distort the character of the favela", as stated later by the writer Jorge Amado. Mauro perfectly controlled the film's composition, incorporating, in the dramatic story, comic scenes and emotional moments, exposing his artistic intentions with the statement "I simply took the favela's life as it was and documented it" (Dennison, Shaw 2004, 49).

Providencia, the first Brazilian favela, was built in 1897, by soldiers who arrived in Rio to receive their payment from the government, for the army's success in stifling the peasant uprising, in the North - Eastern Brazil, during Canudos Warm in Bahia. Not getting the money they were promised, they chose not to leave and the majority settled, in Rio, in improvised shelters. Considered in the 1920s by the inhabitants of Rio as the main source of crime and by the government as an obstacle to urban development, the number of favelas residents increased in the 1940s, when the housing crisis reached worrying levels, forcing the poor urban population, attracted to the big city by the industrialization proposed by President Getulio Dornelles Vargas, to raise hundreds of ghettos, in the city's suburbs. However, the modern favelas appeared in the 1970s, as a direct consequence of the Brazilian population's exodus, when the locals of the rural areas migrated to the cities, in search of a better life. Once in Rio, low-income migrants faced land and housing high prices, having no choice but to build illegal shelters. Due to a lack of government support and of a program to increase the number of homes, the percentage of these makeshift settlements continued to increase. In Rio de Janiero, between 1950 and 1980, the number of the favelas' residents increased from 170.000 to 600.000 and, at the beginning of the 21st century, the estimates showed that the number of favelas rose to 1.000 . The substantial increase eventually attracted the attention of the Brazilian government, which decided, in the 1960s, to try to eradicate these controversial settlements, by relocating their inhabitants in residential complexes, such as Cidade de Deus, a community made known to the general public, due to the movie, bearing the same name, from 2002. This action was ultimately declared a failure, because, due to faulty planning and limited financial resources granted to the project, the new residential complexes, became, in their turn, in some of the cases, new favelas. In 1991, a study conducted by the Instituto de Planejamento in Rio de Janiero (IPLAN- Rio), claimed that there were a total of 661 favelas in 
the city, gathering 962.793 residents, in 239.678 barracks (Pino 1997, 111). Statistics released by the Brazilian Institute of Geography and Statistics, in December 2011, showed that in 2010, 6 percent of Brazil's population lived in favelas (IBGE, Census, 2010).

Rio's favelas provide the perfect opportunity to investigate how social inequality is represented in Brazil. Inadequate living conditions and poor government support left these settlements exposed to narcotics production and trafficking, thus becoming, in the 1980s, points of interest in Latin America, dominated by gang violence, guns and drugs trafficking. The violence continued to grow and the favelas, through which millions of dollars annually went, became illegally ruled by drugs and weapons dealers. In 2008, the Brazilian government decided to intervene, placing, in the ghettos with an increased crime rate, police guards which, after a series of violent clashes with gang members managed to obtain, in some case, safer living conditions for the local communities.

The favelas are considered weak points in the city's infrastructure, a mistake that Brazilian urban planners and architects are trying to delimit themselves from, proposing forced removals in newly built assemblies, or building cable cars above these communities, encouraging a strange intrusive tourism. Or, they want them to become invisible. But the inhabitants of the slums, started working in order to have a honest representation of the way their life is presented, especially insisting on the need to have decent living conditions and, also, illustrating how this urban typology has developed over the decades, independent to the existing urban proposals, through organisations like Favelas in Mare or Raize em Movimento do Complexo do Almao (Palmer, Nitsch 2014, 9).

\section{Tio Lino from Rocinha favela}

Rocinha, located in Rio de Janiero, is the largest favela in Brazil. Built on a steep hill, surrounded by rich vegetation, this favela housed between 150.000 and 300.000 inhabitants in the 2000s and, in 2017, the English publication The Economist reported that Rocinha had a population of 100.000 inhabitants, on an area of 250 acres $(1 \mathrm{~km} 2)$. Being considered an urbanized slum, with a considerable number of buildings made of brick or concrete, with rudimentary sanitary facilities, with a sewerage system and electricity, Rocinha has, compared to other ghettos, a stronger infrastructure, but also an unexpected large number of local services (clothing stores, grocery stores, confectionaries, pastry shops, bank branches, pharmacies and even plastic surgery offices).

Frustrated by the worrying state of the education system in these communities, the nongovernmental organizations in the favela try to work with the large number of students who have not yet accumulated the basics (reading, writing, arithmetic) in schools, creating solutions to solve the ongoing problems in this sector, as well as the deficiencies that appear as a consequence of the insufficient number of schools, the low quality teachers, the violence and crime present in these areas. Although results have already started to appear and the number of students present in the classrooms has started to increase in the recent years, partly due to the communities which have started to get directly involved in this process, there are still a large number of functional illiterates, who finish the courses of the Brazilian schools (The Brazilian Report 2017). Despite the general progress, as a result of the increase in the number of students enrolled in Brazilian schools, who now have access to education and a significant increase in the number of those who attend the course of educational institutions, in a period of fifteen years, according to the OECD report from 2010, there is still a consistent percentage 
of illiteracy, among students who still have problems when they have to solve basic exercises, read or write. One of the non-governmental organizations in the Rocinha favela is Tio Lino (Uncle Lino), who was created by a tenant of the favela, in 2002, who wanted to create a safe space for the inhabitants of this community who decided to change their ways. He encouraged the Brazilians in Rocinha to give up their weapons, which were considered by the population in the ghettos, the only way to communicate, so that they could safely surrender their weapons to the police. Everyone who comes to the NGO is involved in cultural, artistic projects, is taught to write, read, or simply have a safe place where they could meet with volunteers eager to help. The most important project, which lasts, already, for more than two decades, is called "Rocinha Waldorf Art Project - Trade your weapon for a brush", who tries to gather all artistic creations made by the inhabitants of Rocinha, in an attempt to provoke the Brazilian population to see residents of this community other than just violent and dangerous individuals and deprived of a basic school education. Following Lino's death, two years ago, his daughter, Iris, sponsored by two volunteers from England, continues her father's vision, under the name ACE (Accelerating Community Empowerment).

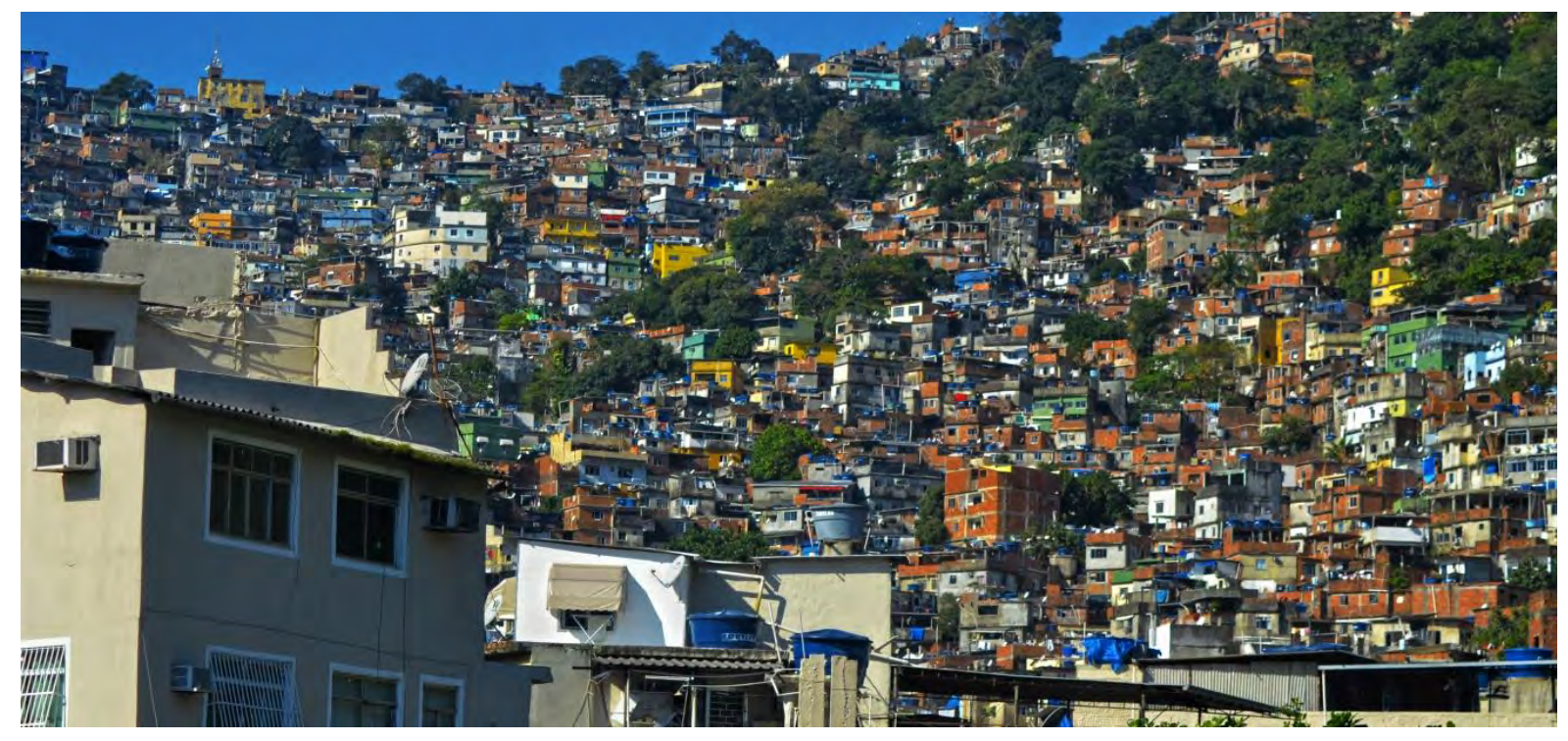

Fig. 1. Rocinha favela.

Source: Image by Gențiana Dumitrașcu

\section{Objectives}

Our objective was to make a different kind of architectural analysis, a possible first step of a larger study, using the defining components of comic strips, while experiencing, first hand, the overlapping layers of architecture in Rocinha and connecting with its residents. We considered that it would be a valuable exercise to analyze the architecture of the favela, to talk with its inhabitants, to develop a comic strip, with the children from the NGO, detailing how it is to live surrounded by the chaotic architecture of Rocinha and, of course, to have the opportunity to experience the favela, in safe conditions. 


\section{Materials and Methods}

Using the characteristic elements of the hybrid medium of graphic representation, the comic strip, which combines in its structure narration, space and movement, alongside another fellow architect, Andrei Dumitrașcu, we conducted a 2 weeks drawing workshop, with a fraction of the children who attended Tio Lino's classes. The short narrative, a collective product, the result of the discussions we had with the 9 students, was their attempt to capture as much of their individual opinions as possible, about the experience of living in their community. We discussed, debated and then drew, along with them, how they perceived the favela, how the road from home to school looks, or the one from home to the NGO, or what is their favourite place in the favela. We tried to urge them to identify a series of problems that they see in the favela and to encourage them to try and find solutions for them.

Also, we wanted to document as much information as possible from our daily visits in the favela, and so, we decided to conduct a number of interviews with the older residents of the favela. These discussions had a short questionnaire, which we prepared before the visit to Brazil, but which we adapted for each person and situation. The short survey constituted of 5 questions: How long have you been living in the favela? Are you the owner of your home? Could you name the most pressing issues with which the residents of the favela struggle every day? Could you name your favourite 3 things about living in Rocinha? What is the most important information which residents of Rio, politicians, or foreigners need to know about the Rocinha favela?

\section{Fragments from the journal: incursion into the favela}

The image of Rocinha is overwhelming. I think that, for the eye, mainly trained with the urban landscapes specific to the South-East of Europe, is difficult to record, in a few moments, the large amount of information of colours, shapes and textures, that were offered by the biggest favela in Rio, every time we got from the subway station to start our route to Tio Lino.

In order to get to the NGO, you had to take a narrow path, which we walked accompanied, during the first two days and then alone, through the small alleys of an improvised market, in order to get to one of the recommended entries in the favela. Most of the time, we did this, without saying too many words, trying to practice some of the advices we received, in order to be safe. The covered and crowded market consisted of a row of multicolored stalls, on which were displayed, without any particular order, an overwhelming quantity of clothing products, imitations of all kinds of jewelry, toys, umbrellas, watches etc. Among the stands, you could identify a small confectionery or pastry, which did not suffer, at any hour of the day, from a lack of customers. Then, after going out again, in the surprisingly strong sun for a late winter, early spring, at the first intersection, relatively generous, in terms of Rocinha's infrastructure, you had to venture down the narrow alleys, lined with makeshift shops on the ground floor, you had to bypass the children, who were happily running in all directions, the adults acting as guardians, measuring you from head to toe and ranking you easily and correctly in the category you belonged to (local, occasional visitor, volunteer, policeman, drugs or weapons trafficker). At times the residents were too preoccupied with settling their disputes, or just enjoying a sunny afternoon, dancing to the beats playing from small radio sets placed directly on the sidewalk. We were warned, in advance, that in the favela we could only be stopped by individuals belonging to the most important categories: drug dealers or policemen. However, there was a small possibility that this might happen, because the members of the two sides 
had extensive experience in analysing the passersby and could quickly realize that, although we were trying to lose ourselves among the 150,000 inhabitants, we were, certainly, foreigners, most likely, volunteers. Although favelas are considered to be the most dangerous places in Brazil, we felt, during the weeks spent in Rocinha, much more secure venturing on the narrow alleys than outside of them. On the streets of Rio you had to be careful with any movement you were making, you had to stay away from the large number of not so peaceful homeless people (a large portion of them were suffering from drug addiction), you had to constantly try to identify the possible pocket thieves, of any age, who could also turn violent. But, in Rocinha, we just had to stay out of the way of an eventual dispute between drug traffickers and policemen who often made raids in the favela, in order to not become collateral victims of their conflict. Otherwise, for the two sides in the community, which are always in conflict, we did not present much interest.

On the main streets, which ascend and descend the hills on which the favela is built, buses, minibuses and motor-taxis, the main means of transportation to and from Rocinha, are constantly circulating. The motor-taxis are the cheapest and most exciting way of travelling, due to the skillful movements, which drivers make per millimeter. Along the main arteries are constructed the tallest buildings, in some cases, six, seven floors, with shops located on the ground floor, which are, in most of the cases, decorated with stone or tiles and always painted in strong colours. In the case of residential buildings, located deep in the favela, the residents most often choose to leave the exposed brick, using no other finish, and the roof is (as in the case of Tio Lino's headquarters) a sheet of thin metal, decorated with antennas and blue water tanks. Most of the windows, especially the ones on the ground floor, those on the lower floors and the entrances are protected by grates, something that is found in most of the buildings in Rio, regardless of the area in which they are located. On the other hand, to the interior of the houses is given a lot of attention, being painted in bright colours, finished with tiles and each room is accompanied by a fan.

\section{The results of the comic strip experiment}

From the discussions and the drawings of the 9 students attending the workshop, we have concluded that they gladly run, in the narrow streets of the favela, that they feel overwhelmed, not only when they have to draw them, by the large number of buildings that surround them, but adore the vivid colours in which they are painted and they feel entangled by the large number of cables present at each corner, used by residents to steal electricity. Although they are young, they easily observe and are affected by a large part of the problems Rocinha faces: lack of safety, high number of adolescent mothers (one of the students, when she was urged to illustrate what she considers to be a problem of the favela, presented the tragedy of a cousin who became pregnant, and she was very worried that she will not have money to feed or clothe her new born), lack of food, especially in the case of large families, but also poor sanitary conditions, present in most of the favela. After identifying the problems, the students offered small solutions to the problems that they observed, mostly, defined by the innocence, still unaltered, specific to their young age. The most original solutions, as well as illustrations, were provided by Maycon, a brilliant 11-year-old student, from a poor family with seven other brothers, who, however, encountered problems when he had to insert texts in his drawings, or read us what he had written.

It was very difficult, from the first moment, to determine the students who participated in the experiment to stay focused on the drawings and to engage them in a detailed discussion about 
what they want to draw. It happened, in the case of three little girls between the ages of 8 and 10 years old, that they wanted to finish very quickly what they had to draw in a particular day, when they realized that it may not be the easiest exercise they had to do, until then. In a subsequent discussion about how our work sessions are evolving, with one of the volunteers who had spent 2 years working in the NGO, she shared with me her experience, explaining that they are rarely encouraged in school, to keep their concentration, for a longer period of time, and a moderate perseverance is an exception that is found, in the case of the few students, whose parents are very involved in their education, not in the majority.

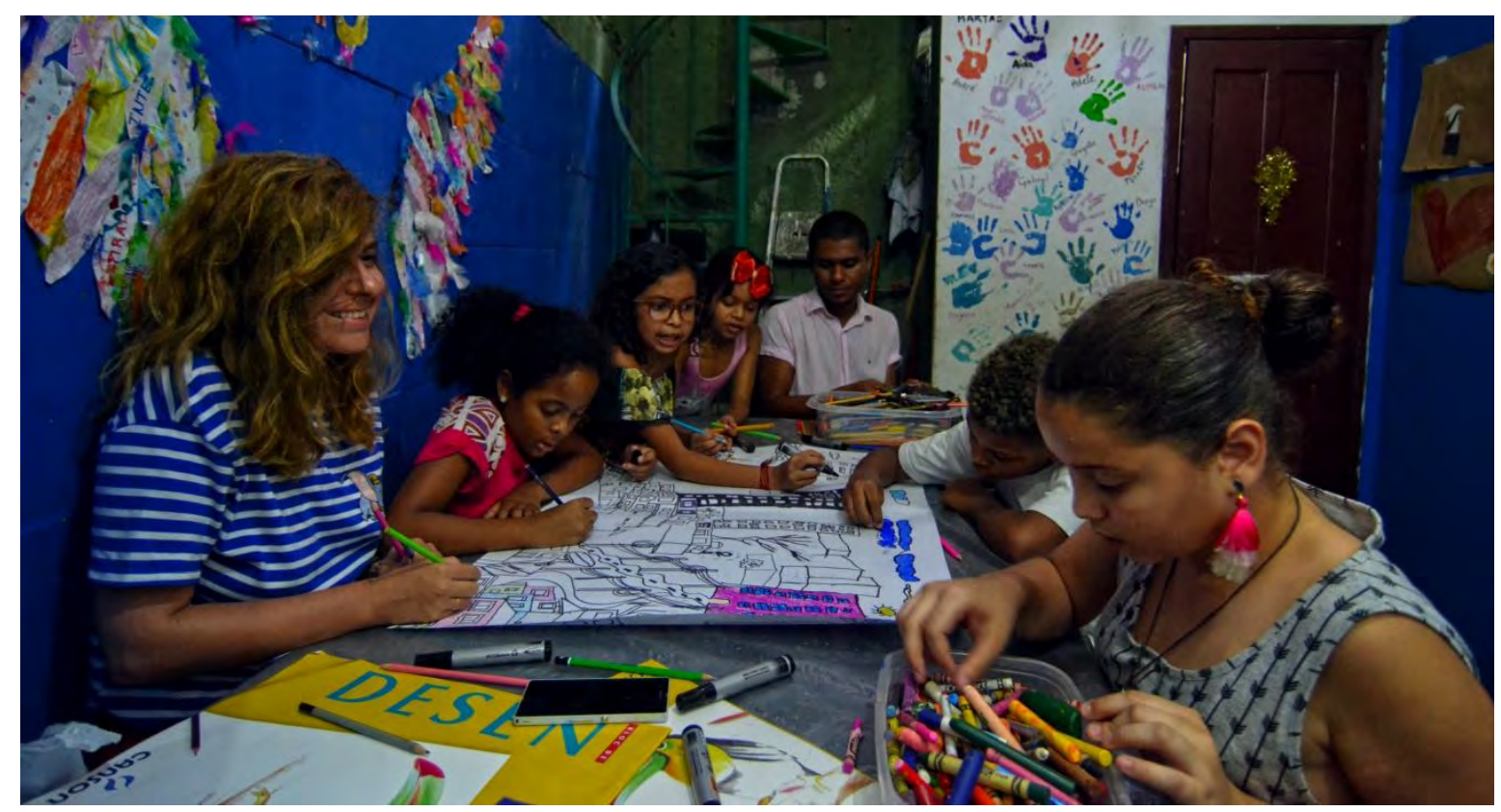

Fig. 2. Students of Tio Lino.

Source: Image by Andrei Dumitrașcu

Because, unfortunately, the time spent with them was limited and we would not have had the opportunity to explore more representation techniques, we proposed to the students to approach this exercise only in black and white tones, this time, and at the end of the sessions, to make a large, collective board, in coloured pencils, showing our perception of the favela. The most intense disputes came between them, when, we began to limit the access to the eraser. We wanted to explain that, it is very important to try to think in detail what we want to draw before we do, but also, that anything that they draw will not be considered to be an error, but only a stage of the process, which we can modify or adapt, once it appears in their illustrations. In this chapter, we had small victories, during the days that followed, but when the discussions became too heated, because a seemingly wrong line, could often make the eyes of a 7-year-old very watery. We made a little concession and I asked them to let me help when erasing the unwanted lines, or to adapt, what they considered to be catastrophic mistakes in their drawings. The lack of exercise to make a constant effort could be easily observed at this point of the experiment.

Although they were clearly aware of the crowding of information in the favela, we managed to gradually convince them to add, one by one, as a result of our conversations and encouragements, one more layer of buildings, windows (and persuading them to leave the rectangular shape and also explore other shapes), cables, satellite dishes, water tanks, dogs, cats, motorcycle taxis etc. 
Carrying on conversations with the inhabitants of the favela, I learned that: there is no urban regulation; mutual respect between neighbours is decisive when discussing a new addition of a building; the advice of an architect or an engineer is used only for buildings taller than three stories, and for the rest of the buildings a small group of workers, or members of the family, are involved in both the designing and construction of the building; you can sell the surface of the roof of the house where you live, to another owner, so that he can build his own above your home (that is, if another member of your family does not want to settle in that space); the tenants do not pay for electricity, water or the internet (all these are being stolen) and although the residents of the community still struggle with diseases that appear as a consequence of the lack of adequate sanitary conditions (the garbage is rarely collected in time, and the sewage system has many irregularities), the Brazilian government makes more investments in Rocinha. However, not all investments are appreciated by the Brazilians in this community, one of the most disputed being the bridge built by the architect Oscar Niemeyer, which costs about nine million dollars and connects the favela with the rest of the city of Rio. The residents of the community are proud when they look at the work of the renowned Brazilian architect, but at the same time, they think that the generous amount of money, used to design and build it, could have been used to solve many other urgent problems that the ghetto faces daily.

Most of the residents want to become owners of the land on which they built their homes and they don't agree with the relocation programs offered by the Brazilian government. They think that, instead, their communities could benefit from investments that would support: proper sewerage system, widening of arteries and garbage collection.

Adams, 28, who works in Rocinha, with the non-governmental organization Tio Lino and lives in Santa Marta, another favela in Rio, with whom we spent most of our time, he being our guide in the favela, explained to us, in detail, how we should behave, where and when we need to go to be safe, but also what to say to drug dealers and policemen when they ask us what we are looking for in that part of the city. He, also, talked to us about what impediments that those living in the favela are facing, but, choose to work outside of it. Of course, you have to be on permanent alert in order not to become a collateral victim in the clashes between police and drug cartel representatives. Residents have special online groups where they announce each other if an exchange of fire is taking place, to avoid entering or leaving the favela at that time and to stay safe. As is often happens, in the case of several residents of this community, he lost two jobs because, in an attempt to avoid repeated violent clashes between the two sides, he was late to work, or was forced, without the possibility of to give a notice, to miss a whole day.

\section{The emotional impact of the favela}

The historians Alba Zaluar and Marcos Alvito published a letter found in the national archives, written on November 4th, 1900, in the book Un Seculo de Favela, published in 1998. Only three years after the favela Morro da Providencia was born, it had already begun to have an unfavorable reputation, according to the complaints of an officer, who was trying to describe the difficulties encountered in trying to combat the crime in this slum:

Policing is impossible in this area, rife with deserters, thieves and squaddies. There are no streets, the houses are all made of wood and covered in zinc, and there isn't a single gas light on the whole hill. (Douglas 2016) 

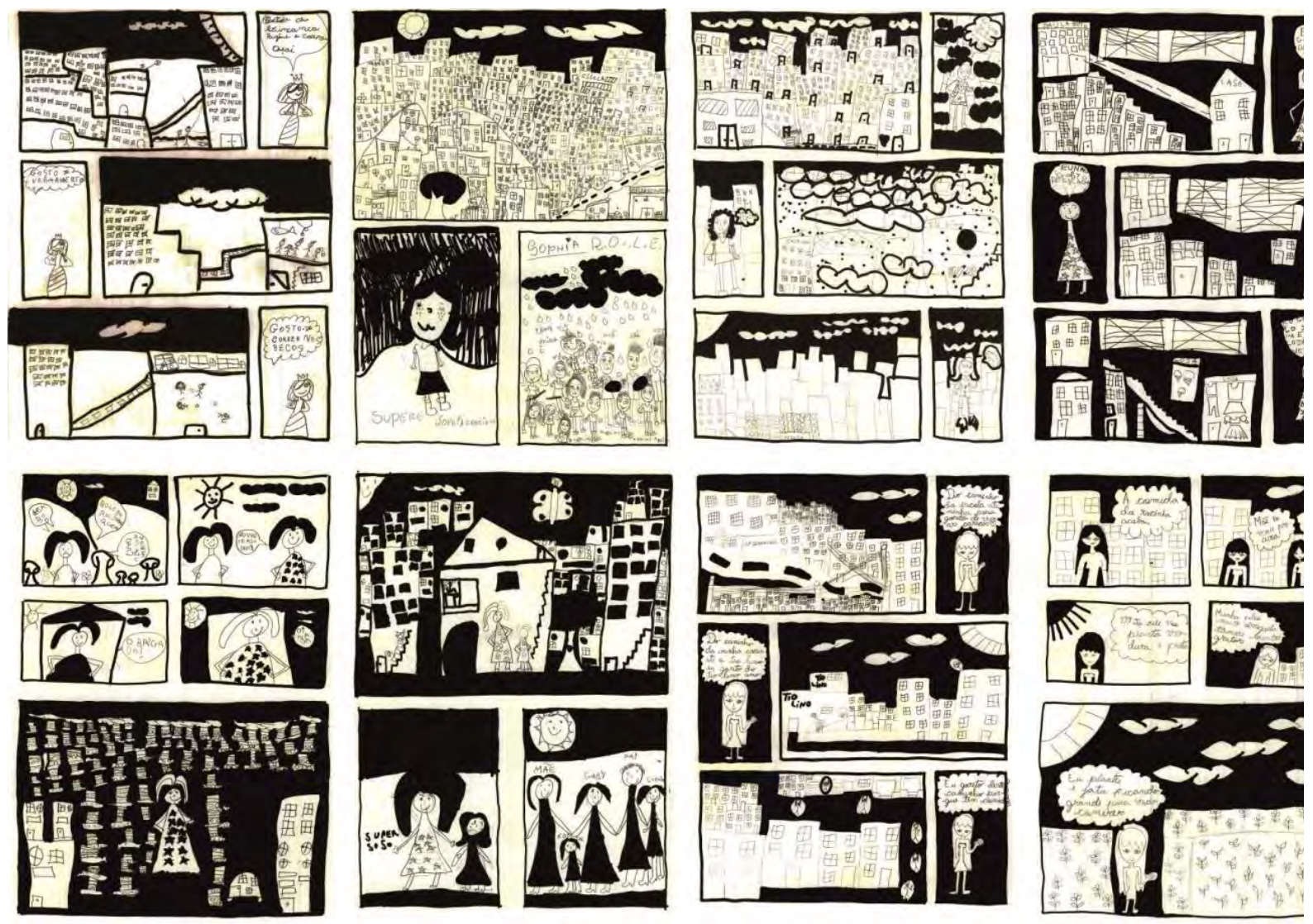

Fig. 3. Part of the architectural comic strip made by the Tio Lino students.

The problems that arise during the fight against crime in these areas and the complex implications of the conflict between drug traffickers and representatives of the Brazilian government still influence today the nature and quality of civic life in favelas. Cartels are well consolidated and their tumultuous relationship with the state's representatives dominates the social life in ghettos.

In the weeks spent in Rocinha, we were also the spectators of a difficult moment, when during a police raid a number of five suspects were arrested. It all happened when, one afternoon, we were getting ready to go into the favela, to start our drawing session with the students from Tio Lino. On the way to the NGO, we encountered many young, armed civilians, prepared for a new conflict with the Brazilian police and when we arrived at the Tio Lino building, the fire exchange began. My first thought, being a person who was not used with the noise of fire guns, was that what I hear are fireworks. Of course, they weren't. Fortunately, no one was injured in the conflict. Nothing had a bigger impact on me than the children's reaction. I asked, in a beginner's Brazilian Portuguese that I had struggled to learn before this trip and that I was stubbornly trying to exercise throughout the days spent in Rio, if they are afraid. They just smiled at me and answered that no, "we have become used to it already, we are just not going home alone today, we will be expecting our mothers to come and pick us up." That was their home, full of shortcomings, dangerous and very often simply chaotic, but full of energy and colour and they had adapted to everything which represents, at this moment, the favela Rocinha. 


\section{Instead of a conclusion}

As much as you, theoretically, prepare for the experience of working in the Rocinha favela, if you don't explore, in detail, the particularities of the space of this city in a city, you cannot conduct an honest and coherent analysis. While studying this community it is necessary to take into account all the complex layers that conducted to the present state of the living conditions in this favela. Drawing and discussing the architecture of the favela, with the students of the NGO, gave us the opportunity to talk about a large part of the locals' problems. Our effort to finish the project in less than perfect conditions, gain the trust of some of the older residents, who agreed to talk to us more, enriching our analysis. This experiment can be a starting point for a longer collaboration, in which, we can, after finishing our study, propose small interventions to improve some of the living conditions in the Rocinha favela.

\section{References}

Ahrens, J. (2010) and Meteling A. Comics and the City. Urban Space in Print, Picture and Sequence. New York: Continuum.

Bachelard, G. (2003). Poetica spaţiului. (I. Bădescu, Trans.). Piteşti: Paralela 45.

Dennison S, Shaw L. (2004). Popular cinema in Brazil. Manchester: Manchester University Press.

Douglas, B. (2016): The story of cities \#15: the rise and ruin of Rio de Janeiro's first favela. The Guardian, on-line article.

Eisner, W. (2008) Graphic storytelling and visual narrative: principles and practices from the legendary cartoonist. New York: W.W. Norton \& Company Inc.

Erdogan, A. (2019). The city in crimson cloak (Kirmizi Pelerinli Kent). București: Polirom.

Pino, J.C. (1997). Sources on the history of favelas in Rio de Janeiro. In Latin American Research Review (Vol. 32, no. 3). (pp. 111-122). The Latin American Studies Association. Jstor Academic Database.

Robinson, S. (2019). A-ți face cuibul: Trup, Casă, Minte (Nesting: Body, Dwelling, Mind). (Stanislav C. , Trans.). București: Arhitext.

The Brazilian Report (2017). Brazil's failed educational system creates illiterate students. The Brazilian Report on-line article. 